\title{
Today's Knowledge Economy and Firm Growth: A Study of Small to Medium Enterprises in the Manufacturing Sector of Zimbabwe
}

\author{
Faitira Manuere (Corresponding author) \\ Chinhoyi University of Technology \\ Tendai Joseph Mabvure \\ Chinhoyi University of Technology \\ Obert Sifile \\ Chinhoyi University of Technology \\ Department of entrepreneurship and business management \\ Piason Viriri \\ Chinhoyi University of Technology
}

Received: April 19, 2018 Accepted: June 20, 2018 Online published: June 25, 2018

doi:10.5296/jpag.v8i2.13318 URL: https://doi.org/10.5296/jpag.v8i2.13318

\begin{abstract}
Small to Medium Enterprises (SMEs) in Zimbabwe are characterized by high failure rates. This failure rate has been attributed to poor leadership, poor funding and lack of technology. The contribution of knowledge management to SMEs growth has received very little attention from researchers in Zimbabwe. Hence this study makes an effort to investigate the relationship between knowledge management models and SMEs growth. Data were collected from 32 SMEs owners in the Makonde District of Zimbabwe. Pearson's product moment was used as a tool for data analysis. The independent variables are knowledge creation, knowledge acquisition, knowledge storage and knowledge dissemination. The dependent variable is SMEs growth. The findings show that knowledge management positively correlates to SMEs growth. To that end the study recommends that effective models of
\end{abstract}


knowledge management must be used to boost the growth of SMEs in Zimbabwe.

Keywords: knowledge economy, small to medium enterprises, firm growth, Zimbabwe and failure rate

\section{Introduction}

The concept of SME growth means many things to many people. According to Barkham et al (1996), firm growth refers to an increase in revenue, production capacity, employment and an increase in the use of raw materials and power. Delmar et al (2003) argues that business growth is difficult to define although easy to measure using changes in sales, assets, and employment, productivity, profits and profits margins. Delmar et al (2003) claim that employment and sales are critical measures of business growth. According to Davisson et al (2010), SMEs that have growth motive will eventually become a large organisation. Several factors have been identified that influence SME growth and these factors include company resources, the human factor in production, and the external and internal environment of the company and market features (Levratto, 2010). Scott and Bruce (1987) and Howard (2006) argue that SMEs experience several stages of growth. These stages are given in Table 1:

Table 1. The stages of SME growth

\begin{tabular}{l|l|l|l}
\hline Stage & Management Role & Management Style & Organisation Structure \\
\hline 1. Inception & Direct supervision & $\begin{array}{l}\text { Entrepreneurial } \\
\text { individualistic }\end{array}$ & Unstructured \\
\hline 2. Survival & Supervised supervision & $\begin{array}{l}\text { Entrepreneurial } \\
\text { administrative }\end{array}$ & Simple \\
\hline 3. Growth & Delegation/co-ordination & $\begin{array}{l}\text { Entrepreneurial } \\
\text { co-ordinate }\end{array}$ & Functional centralized \\
\hline 4. Expansion & Decentralization & $\begin{array}{l}\text { Professional } \\
\text { administrative }\end{array}$ & Functional decentralized \\
\hline 5. Maturity & Decentralization & Watchdog & $\begin{array}{l}\text { Decentralized functional } \\
\text { product }\end{array}$ \\
\hline 6. Integration & Centralization/co-ordination & $\begin{array}{l}\text { Entrepreneurial } \\
\text { co-ordinate }\end{array}$ & Functional centralised \\
\hline
\end{tabular}

Source: Scott and Bruce (1987)

In the first stage, the SME is just beginning and is in the phase of developing products, markets and a brand name. In the second stage the SME begins to increase sales, revenues, products, markets and employees. Stage three is characterized by professionalization and formalization of organizational activities. The fourth stage addresses problems being faced by the company. In the fifth stage, new products are developed for the new markets. The sixth stage develops an infrastructure that integrates all strategic business units. The seventh stage develops models to guarantee the survival of the company in the long run (Scott and Bruce, 1987; Storey, 1994; Howard, 2006). According to Storey (1994), SME growth is based on three critical pillars, such as, the entrepreneur, strategy and knowledge management models adopted by the firm. This is illustrated in Figure 1: 


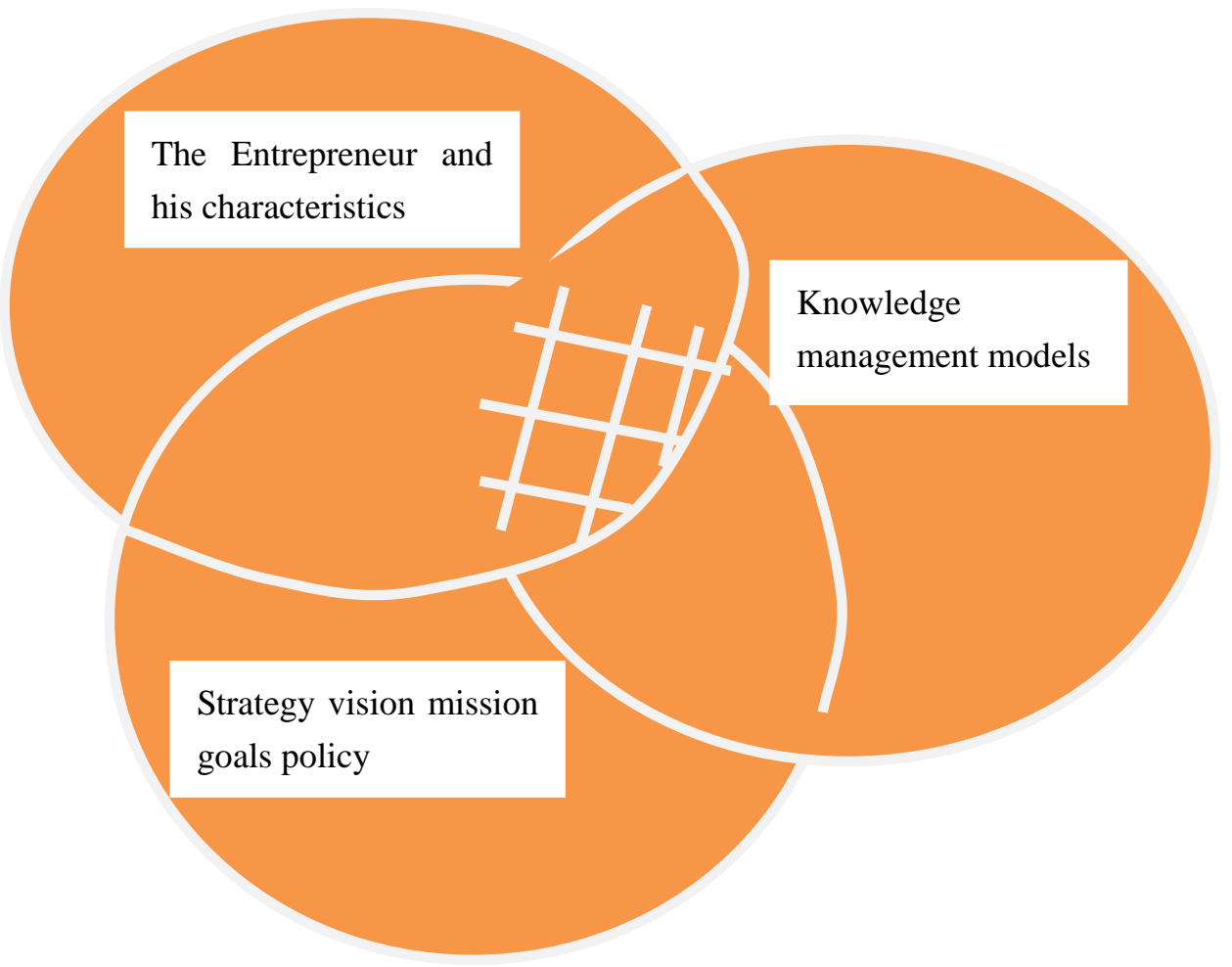

Figure 1. Three pillars influencing SME growth

Source: Storey (1994)

The theory of SME growth developed by Storey (1994) proposes that the three pillars determining firm growth include; the demographic characteristics of the entrepreneur (age, sex, education, motivation), company strategy (vision, mission, core values, corporate culture, firm goals and policy), and knowledge management models (knowledge application, acquisition, storage and dissemination).Storey(1994)argues that the three pillars of SME growth are complementary and not independent from each other, hence they are depicted as intersection circles. Table 2 shows some of the factors that affect the growth of SMEs.

Table 2. Factors affecting growth in SMEs

\begin{tabular}{l|l|l}
\hline Entrepreneur Factors & Firm Factors & Strategy Factors \\
\hline 1. Motivation & 1. Age & 1. Workforce training \\
\hline 2. Unemployment & 2. Sector & 2. Management training \\
\hline 3. Education & 3. Legal form & 3. External equity \\
\hline 4. Management experience & 4. Location & 4. Technological sophistication \\
\hline 5. Number of funders & 5. Size & 5. Market positioning \\
\hline 6. Prior self employment & 6. Ownership & 6. Market adjustments \\
\hline 7. Family history & & 7. Planning \\
\hline 8. Social marginality & & 8. New products \\
\hline 9. Functional skills & & 9. Management recruitment \\
\hline 10. Training & & 10. State-support \\
\hline 11. Age & & 11. Customer \\
\hline 12. Prior business failure & & 12. Competition \\
\hline 13. Prior sector experience & & 13. Information and advice \\
\hline 14. Prior firm size experience & &
\end{tabular}

Source: Storey (1994) 
Table 2 shows the three sets of factors that have a bearing on the growth and development of SMEs the world over. The first set relates to entrepreneur factors. These are the factors that pertain to the characteristics of the SMEs owner or manager. The owner's beliefs and worldview affect the way the entrepreneur manages the organization. The second set of factors refers to the characteristics of the firm. The size of the firm, the location of the firm and the market being served by the firm are important ingredients in the growth and deployment of the organization. The third set of factors has to do with strategy factors, such as, employee training and development, innovation, research and entrepreneurship development. These factors are important in that they relate the achievement of objectives to company growth and development. However Table 2 does not mention knowledge management models and their significant to SMEs growth and development.

\section{The Review of Related Literature}

Several authorities have agreed that knowledge is a critical resource that guarantees firm growth and survival in the long run (Drucker, 1993; Davenport and Prusak, 1988). Organizational knowledge represents the firm's thinking power that drives the needed innovation, product development and competitiveness (Palby and Taylor, 2000). According to Bose (2004), knowledge refers to "unjustified true belief" that knowledge is a product that can be measured, manipulated and explained using facts at hand. On the other hand, Alavi and Leidner (1999) define knowledge as a group of concepts (beliefs, judgments, philosophies, values, norms, methodologies and culture) that can be used to enhance an individual's capacity to plan, evaluate and build physical artifacts from ideas.

Organizational knowledge refers to a group of concepts (idea generation, product development, marketing activities, distribution logistics, sales growth, employee motivation, risk management and firm reputation) that are used by the organisation to enhance company performance, (Nonaka and Takeuchi, 1995). Organizational knowledge is defined as the sum total of all the company activities plus the ideas generated from the vagaries of both the external and the internal environment of the firm, (Nonaka and Takeuchi, 1995). Some scholars define organizational knowledge as a series of ideas represented by the company vision, company mission statement, company strategy, government legislation, organizational structure, corporate structure, competition, customer expectations and buyer and seller relationships (Alavi and Leidner, 1999). The literature on organizational knowledge provides two groups of knowledge, such as tacit and explicit knowledge (Polanyi, 1958). Tacit knowledge is possessed by an individual in the form of formal education, job experience, beliefs, philosophies, mathematics models and theories, hence tacit knowledge cannot be formalized (Polanyi, 1958; Nonaka and Tekeuchi, 1995). On the other hand, explicit knowledge is tangible and housed in corporate culture, information systems and company activities (Polanyi, 1958; Nonaka and Tekeuchi, 1995).

Tacit knowledge in organizations is difficult to exploit because it resides in individual employees. When employees are not well motivated production processes are mostly affected. On the other hand explicit knowledge is practically useful in organizations. Explicit knowledge is always stored in the form of company programmes, such as, meetings, 
company policies and company products.

\section{Knowledge Management}

According to Alavi and Leidner (1999), knowledge management is a process in which organizational knowledge is captured, acquired, organized and disseminated among employees with the sole purpose of improving organizational activities. Knowledge management is a deliberate action made by the management to transfer the needed knowledge to all internal stakeholders so that the employees can share and apply the information to increase firm performance (Devenport and Prusak, 1998).Akram et al (2011) define knowledge management as a business model that is used by organizations to "generate value from their intellectual and knowledge based assets." A number of scholars argue that knowledge management is the deliberate operationalisation of both tacit and explicit knowledge in order to achieve organizational objectives (Alan, 2012). Akram et al (2011) acknowledges that there is a positive relationship between innovation and knowledge management. On the other hand Carneiro (2000) argues that there is a positive relationship between knowledge management, innovation and firm competitiveness. Darroch (2005) explains that the process of knowledge management facilitates the effective implementation of firm strategy. A number of scholars argue that knowledge sharing in the organisation translates into different types of innovation, as shown in the list below (Schumpeter, 1934):

New product;

New methods of production;

The exploration of new market of production;

New source of supply;

New ways to organize business.

\section{Knowledge Management Models}

Table 3 shows knowledge management models that can be used to foster the growth and development of SMEs;

Table 3. Knowledge management models

\begin{tabular}{|c|c|}
\hline Model & Narration \\
\hline 1. Knowledge creation & $\begin{array}{l}\text { The knowledge comes primarily from the experiences and skills of } \\
\text { the employee. Knowledge is created as people determine new ways } \\
\text { of doing things or develop know-how. Sometimes if the knowledge } \\
\text { is not residing in the organisation, external knowledge is brought in. }\end{array}$ \\
\hline 2. Knowledge capturing & $\begin{array}{l}\text { The knowledge that is created needs to be stored in its raw form in a } \\
\text { database. Most organisations use many different types of } \\
\text { knowledge repositories to capture the knowledge. }\end{array}$ \\
\hline 3. Knowledge refinement & $\begin{array}{l}\text { New knowledge must be placed in context so that it is actionable. } \\
\text { This is where human insights or tacit knowledge is captured and } \\
\text { refined along with explicit knowledge. }\end{array}$ \\
\hline 4. Knowledge storage & $\begin{array}{l}\text { Codification of tacit and explicit knowledge helps in making the } \\
\text { knowledge understandable so that it can easily be stored for use at a } \\
\text { later date. }\end{array}$ \\
\hline $\begin{array}{l}\text { 5. } \begin{array}{l}\text { Knowledge } \\
\text { management }\end{array}\end{array}$ & $\begin{array}{l}\text { Like a library, knowledge must be kept current. It must be reviewed } \\
\text { to verify that it is relevant and accurate. So, most fortunate } \\
\text { companies have well defined departments that actually take care of } \\
\text { keeping the knowledge current. }\end{array}$ \\
\hline
\end{tabular}


6. Knowledge dissemination
Knowledge must be made available in a useful format to anyone in the organisation who needs it anywhere and anytime. The new technologies like group ware, internet/intranet and other DSS technologies help in the dissemination of knowledge. (Base, 2004).

Source: Zack (1999).

Numerous scholars have argued that innovation, firm performance, employee motivation and customer satisfaction are all a function of knowledge management models (Prusak, 1997). Knowledge management processes are translated into products, services, management processes and business models in order to enhance the capacity of the organisation to attract new customers, to increase the market share and finally to increase employee productivity, (Chai and Gregory, 2003). In summary, knowledge management is the incubation centre for all forms of innovation, research and entrepreneurship development (Prusak, 1997).Figure 2 shows that there is a positive relationship between knowledge management models, strategy creation, firm growth and company performance.

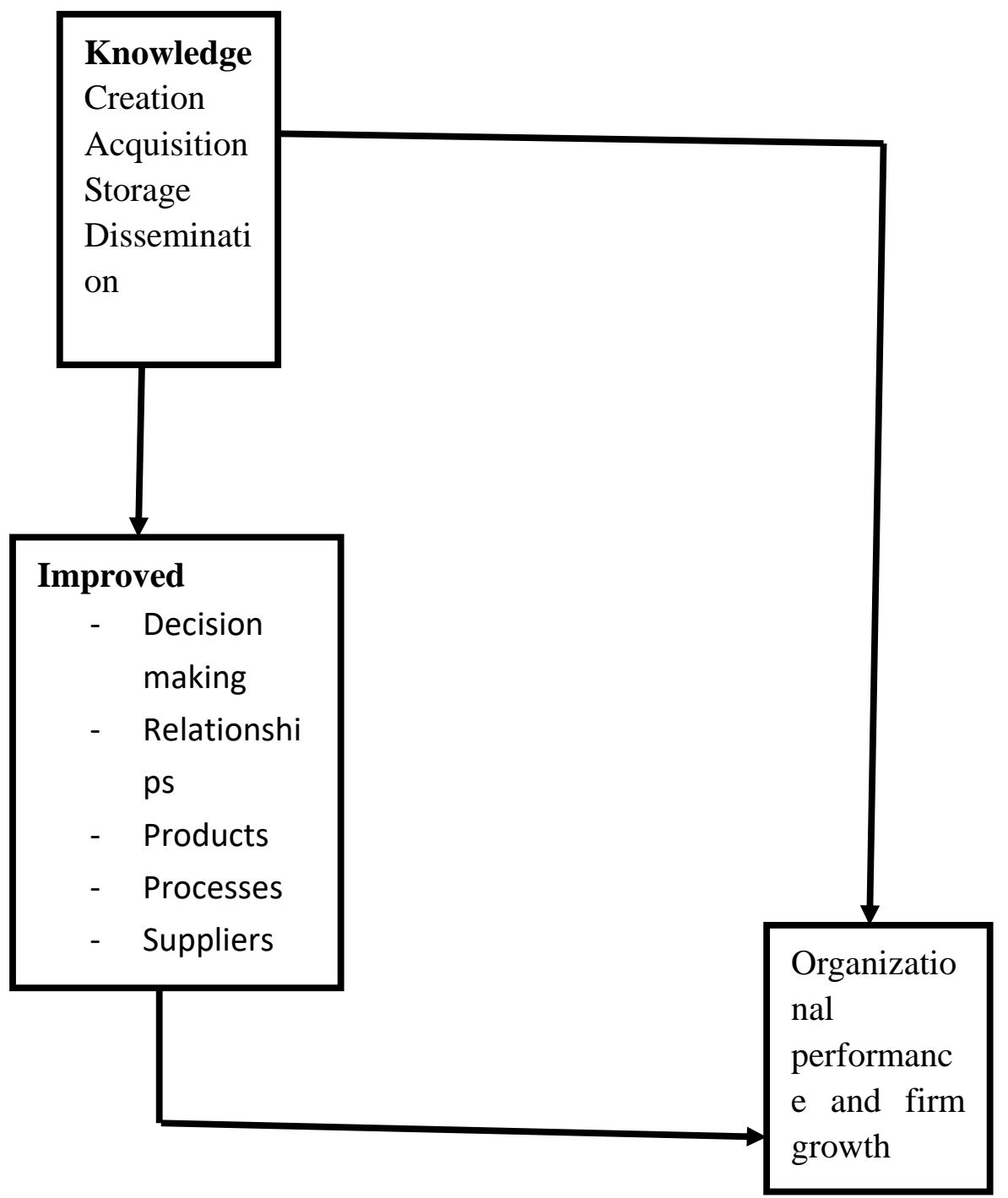

Figure 2. The Conceptual Framework 
Adapted from Zhou and Li (2012).

Figure 2 shows that proper management of knowledge is critical to the performance of the organization. Knowledge management refers to the creation, acquisition, storage, application and dissemination of knowledge. The proper management of knowledge leads to improved decision making, improved customer care and the development of relevant business models. Akram et al (2011) acknowledges that there is a positive relationship between innovation and knowledge management. On the other hand Carneiro (2000) argues that there is a positive relationship between knowledge management, innovation and firm competitiveness. Darroch (2005) explains that the process of knowledge management facilitates the effective implementation of firm strategy.

\section{Objectives}

1. To determine the relationship between knowledge creation and SME growth.

2. To ascertain the extent to which knowledge acquisition affects SME growth.

3. To find out the effects of knowledge storage on SME growth.

4. To establish the effect of knowledge dissemination on SME growth.

\section{Research Hypothesis}

$\mathbf{H}_{1}$ There is no positive relationship between knowledge creation and SME growth.

$\mathbf{H}_{2}$ There is no positive relationship between knowledge acquisition and SME growth.

$\mathbf{H}_{3}$ There is no positive relationship between knowledge storage and SME growth.

$\mathbf{H}_{4}$ There is no positive relationship between knowledge transfer and SME growth.

\section{Methodology}

The descriptive survey design was adopted for this study. The design was used in order to help the researcher to get a detailed knowledge of the subject matter and to describe the relationship between knowledge management models and SMEs growth. The target population consisted of the owners of all Small to Medium Enterprises in the Makonde District of Chinhoyi. The purposive sampling technique was used to collect data from a sample of 35 SMEs owners. Only those SMEs that were registered and had existed for more than five years were selected. Data was collected using the questionnaire approach and both open ended and closed questions based on Likert type scale were adopted. The questionnaire approach helped the research participants to speak their minds freely. Pearson's product moment correlation was used to analyse the data. The study analysed the relationship between four knowledge management models and SMEs growth. The knowledge management models consisted of knowledge creation, knowledge acquisition, knowledge storage and knowledge dissemination. 


\section{Data Presentation and Analysis}

Table 4. Knowledge creation and SME growth

The correlation between knowledge creation and SMEs growth was analysed as follows:

\begin{tabular}{l|l|l|l}
\hline \multicolumn{2}{l}{} & Knowledge creation & SME growth \\
\hline \multirow{4}{*}{ Knowledge creation } & Pearson correlation. & 1 & 0,455 \\
\cline { 2 - 4 } & Sig (2-tailed) & & 0,016 \\
\cline { 2 - 4 } & $\mathrm{N}$ & 32 & 32 \\
\hline \multirow{3}{*}{ SME growth } & Pearson correlation. & 0,455 & 1 \\
\cline { 2 - 4 } & Sig (2-tailed) & 0,016 & 32 \\
\cline { 2 - 4 } & $\mathrm{N}$ & 32 & 3 \\
\hline
\end{tabular}

** Correlation is significant at the 0,05 level ( 2 tailed)

Table 4 shows that there is a positive relationship between knowledge creation and SME growth. This is evidenced by the fact that the P-value $(0,016)$ is less than 0,05 (at 2-tailedtest). This means that knowledge creation contributes significantly to firm growth.

Table 5. Knowledge acquisition and SME growth

The correlation between knowledge acquisition and SMEs growth was analysed as follows:

\section{Correlations}

\begin{tabular}{l|l|l|l}
\hline & & $\begin{array}{l}\text { Knowledge } \\
\text { acquisition }\end{array}$ & SME growth \\
\hline $\begin{array}{l}\text { Knowledge } \\
\text { acquisition }\end{array}$ & $\begin{array}{l}\text { Pearson correlation } \\
\text { Sig (2 tailed ) }\end{array}$ & 32 & 0.666 \\
& N & 0.010 \\
\hline SME growth & $\begin{array}{l}\text { Pearson correlation } \\
\text { Sig (2 tailed ) }\end{array}$ & $\begin{array}{l}0.666 \\
0.011\end{array}$ & \multicolumn{1}{|c}{1} \\
& N 32 & 32 \\
\hline
\end{tabular}

\section{**Correlation is significant at the 0.05 level ( 2 tailed)}

Table 5 shows that there is a positive relationship between knowledge acquisition and SME growth, since the p-value $(0.01)$ is less than 0.011 (at tailed test). The implication is that knowledge acquisition influences SME growth.

Table 6. Knowledge storage and SME growth

The correlation between knowledge storage and SMEs growth was analysed.

\section{Correlation}

\begin{tabular}{l|l|l|l}
\hline & & Knowledge storage & SME growth \\
\hline Knowledge storage & Pearson correlation & 1 & 0.644 \\
& Sig (2 tailed ) & 32 & 0.021 \\
& N & & 32 \\
\hline SME growth & Pearson correlation & 0.644 & 1 \\
& Sig (2 tailed ) & 0.021 & 32 \\
\hline
\end{tabular}

**Correlation is significant at the 0.05 level ( 2 tailed) 
Table 6 shows that there is a positive relationship between knowledge storage and SME growth as evidenced by the fact that the p-value (0.021) is less than 0.05 (at 2-tailed test). This means that knowledge storage has an effect on SME growth.

Table 7. Knowledge dissemination and SME growth

The correlation between knowledge dissemination and SMEs growth was analysed as follows:

\section{Correlation}

\begin{tabular}{l|l|l|l}
\hline & & Knowledge storage & SME growth \\
\hline Knowledge storage & Pearson correlation & 1 & 0.473 \\
& Sig (2 tailed ) & 32 & 0.019 \\
& N & & 32 \\
\hline SME growth & Pearson correlation & 0.473 & 1 \\
& Sig (2 tailed ) & 0.019 & 32 \\
\hline
\end{tabular}

**Correlation is significant at the 0.05 level ( 2 tailed)

Table 7 of Pearson correlation shows that there is a positive relationship between knowledge dissemination and SME growth. This is evidenced by the fact the p-value (0.019) is less than 0.05 (at 2-tailed test). This implies that knowledge storage has an effect on SME growth.

\section{Discussion of Results}

The analysis carried out shows that knowledge creation contributes to SME growth. The analysis further reveals that knowledge acquisition correlates with SME growth. Knowledge storage influences the growth of SMEs. Knowledge dissemination affects the growth of SMEs in a positive way. Darroch et al (2005) argues that effective knowledge management influences the growth of SMEs positively. Eardley and Uden (2011) posit that knowledge management models, such as knowledge creation, acquisition, storage and dissemination 'provide a knowledge-driven culture' in which SMEs can realize potential growth.Knowledge management processes are translated into products, services, management processes and business models in order to enhance the capacity of the organisation to attract new customers, to increase the market share and finally to increase employee productivity, (Abraham, 2008).On the other hand Carneiro (2000) argues that there is a positive relationship between knowledge management, innovation and firm competitiveness. Darroch (2005) explains that the process of knowledge management facilitates the effective implementation of firm strategy. In summary; knowledge management is the incubation centre for all forms of innovation, research and entrepreneurship development (Eadley and Uden, 2011).According to Lin(2007) the proper use of knowledge management models enable firms to create objectives, policies, and strategies that are relevant to the success of the organization.

\section{Conclusion}

SMEs the world over are struggling to remain competitive. SMEs are facing challenges when it comes to achieving firm objectives. Furthermore SMEs have problems in attracting 
profitable customers. This implies that SMEs must use effective knowledge management models in order to meet the demands of global trade. This study therefore, recommends that SMEs should apply knowledge management models to strategy building in order to remain competitive.A number of scholars argue that knowledge management is the deliberate operationalisation of both tacit and explicit knowledge in order to achieve organizational objectives (Gold et al, 2001).Therefore this study is significant in that it explores news platforms that can be manipulated by SMEs organizations to increase revenue, to improve the quality of their products, to be competitive on the global market and finally to realize meaningful growth.

\section{References}

Akram, K., Siddigui, S. H., Nawaz, M. A., Gauri, T. A., \& Cheema, A. K. H. (2011). Role of knowledge management to bring innovation" an integrated approach. International bulletin of business administration, 4(11), 12-134.

Alavi, M., \& Leidner, D. E. (1999). Issues challenges and benefits. Communications of the association for information system, 7(1), 68-72.

Barkham, R., Gudgin, G., Hart, M., \& Hanvey, E. (1996). The determinants of small firm growth: An Inter-regional study in the United Kingdom. Jessica Kingsley London.

Bose, R. (2004).Knowledge management metrics. Industrial management and data systems, l(3), 457- 468. https://doi.org/10.1108/02635570410543771

Carneiro, A. (2000). How does knowledge management influence innovation and competitiveness? Journal of knowledge management, 4(2), 87-98. https://doi.org/10.1108/13673270010372242

Chai, K., \& Gregory, M. (2003). Bridging Islands of knowledge: It's a framework of knowledge sharing mechanism. International journal of technology management, 7(3), 445-460. https://doi.org/10.1504/IJTM.2003.003133

Darroch, J. (2005). Knowledge management innovation and firm performance. Journal of knowledge management, 9(3), 101-115. https://doi.org/10.1108/13673270510602809

Davenport, T., \& Prusak, L. (1988). Working knowledge: How organisations manage what they know. Boston: MA Harvard business school press.

Davidson, P. (2010). Entrepreneurship and after: A study of growth willingness in small firms. Journal of business venturing, 4, 211-26. https://doi.org/10.1016/0883-9026(89)90022-0

Delmar, F., Davidson , P., \& Gartner, W. (2003). Arriving at the High -growth Firm. Journal of business venturing, 18(2), 189. https://doi.org/10.1016/S0883-9026(02)00080-0

Drucker, P. (1993). Post Capitalist Society, New York: Harper Business.

Gold, A. H., Malhotra, A., \& Segras, A. H. (2001). Knowledge management: An Organisational capabilities perspective. Journal of Management Information Systems, 18(1), 185-214. https://doi.org/10.1080/07421222.2001.11045669 


\section{Macrothink}

Journal of Public Administration and Governance ISSN 2161-7104 2018, Vol. 8, No. 2

Howard, J. L. (2006).Small business growth: Development indicators. Academy of entrepreneurship journal, 12(1), 12-23.

Levratto, N., Tessier, L., \& Zaukri, M. (2010). The determinants of growth for SMEs: A longitudinal study of French manufacturing firms. https://doi.org/10.2139/ssrn.1780466

Lin, H. (2007). A stage model of knowledge management: An empirical investigation of process and effectiveness, Journal of Information Science, 33(6), 643-659. https://doi.org/10.1177/0165551506076395

Nonaka , I., \& Takeuchi, H. (1995). The knowledge- creating company. Oxford University, University Press. Oxford.

Nonaka, I., \& Takeuchi, H. (1995). The knowledge creating company. How Japanese Companies create the dynamics of innovation. Oxford University Press: New York.

Parlby, D., \& Taylor, R. (2000). The power of knowledge: A business guide to knowledge management. Academy of entrepreneurship journal, 12(1), 12-23.

Polanyi, M. (1958). Personal knowledge towards a post-critical philosophy. London. Routledge.

Prusak, L. (1997). Knowledge in Organizations. Boston: Butterworth Publications.

Schumpeter, J. (1934). The theory of economic development. Applied mathematics in engineering management and technology, 5(1), 68-73.

Scott, M., \& Bruce, R. (1987). Five stages of growth in small business, Long Range Planning, 20(3), 45-52. https://doi.org/10.1016/0024-6301(87)90071-9

Storey, D. (1994). Understanding the small business sector, International Thompson Business Press. London.

Zack, M. (1999). Developing a Knowledge Strategy. California Management Review, 41(3), 125-145. https://doi.org/10.2307/41166000

Zhou, K. Z., \& Li, C. B. (2012). How knowledge affects radical innovation: Knowledge base, market knowledge acquisition, and internal knowledge sharing. Strategic Management Journal, 33(9), 1090-1102. https://doi.org/10.1002/smj.1959

\section{Copyright Disclaimer}

Copyright for this article is retained by the author(s), with first publication rights granted to the journal.

This is an open-access article distributed under the terms and conditions of the Creative Commons Attribution license (http://creativecommons.org/licenses/by/4.0/). 